\title{
Studies on the Physiology of Heterocyst Production in the Nitrogen-fixing Blue-green Alga Anabaena sp. L-31 in Continuous Culture
}

\author{
By J. THOMAS AND K. A. V. DAVID \\ Biology Division, Bhabha Atomic Research Centre, Trombay, Bombay-85, India
}

(Accepted for publication 2 February 1971)

SUMMARY

Induction of heterocysts in the blue-green alga Anabaena sp. L-3I is totally inhibited by potassium nitrate in batch cultures whereas in continuous cultures no inhibition is observed at high dilution rates. When nitrate is utilized ammonia accumulates in the growth medium, the quantity of extracellular ammonia declining with increasing dilution rate.

The rate of release of ammonia per cell increases with decreasing density of organisms, and induction of heterocysts is consistently observed when ammonia release per cell exceeds $2 \times 10^{-10} \mu \mathrm{g}$. It is inferred that such excessive release depletes the level of intracellular ammonia causing the induction of heterocysts.

\section{INTRODUCTION}

Many filamentous blue-green algae are characterized by the presence of differentiated cells called heterocysts. These cells have been implicated in a variety of functions such as reproduction, storage, separation of hormogonia and spore formation (Desikachary, 1959; Fay, Stewart, Walsby \& Fogg, 1968). Although heterocysts may perform more than one function, some evidence suggests that they are principally the sites of nitrogen fixation in blue-green algae (Fay et al. 1968).

Of relevance to the question of heterocysts being sites of nitrogen fixation is the general observation that heterocysts disappear in the presence of combined nitrogen (Fogg, I942, I949; Pandey \& Mitra, I962 ; Fay, Kumar \& Fogg, 1964; Stewart, I964; Mickelson, Davis \& Tischer, 1967; Talpasayi \& Kale, 1967; Stewart, Fitzgerald \& Burris, 1968). Compounds which inhibit heterocyst production include nitrate, nitrite, ammonia and other nitrogeneous substances, ammonia being the most effective. However, the mechanism of this inhibition has not been clearly understood. Recently we (Thomas, David \& Gopal-Ayengar, 1970) showed that nitrate per se does not inhibit heterocyst production and that ammonia is most likely to be the ultimate cause for the inhibition. Here we report studies in batch and continuous cultures of Anabaena sp. L-3I to further elucidate the physiology of inhibition of heterocysts.

\section{METHODS}

Anabaena sp. L-3I isolated in this laboratory was grown in batch cultures in I 1. conical flasks containing $500 \mathrm{ml}$. Watanabe's (1960) medium without combined nitrogen. A fermentor assembly fabricated locally, and closely similar to model F-I4 of New Brunswick Scientific Co., New Jersey, U.S.A., was used for continuous culture experiments. Temperature was $30^{\circ}$, light intensity 5000 lux, and depth of algal suspension was maintained at $4 \mathrm{~cm}$. All cultures were aerated at a rate of $21 . / \mathrm{min}$. 
After reaching saturation density, $300 \mathrm{ml}$. of algal suspension grown in batch culture were transferred to the fermentor and $300 \mathrm{ml}$. of fresh nitrate-containing medium added. The suspension, after being allowed to continue as batch culture until saturation density was reached, was switched to the continuous phase by maintaining identical rates of inflow of fresh nitrate medium and outflow of algal suspension. The rate of flow of medium was controlled by a peristaltic pump and outflow of algal suspension was maintained by the chemostatic overflow method.

Daily measurements were made of turbidity, cell number, cell size, heterocyst frequency, filament length and extracellular ammonia. Extinction was measured at $450 \mathrm{~nm}$. using Bausch \& Lomb Spectronic 20 spectrophotometer. Cell number was determined in a Neubauer Levy Ultraplane counting chamber, and cell size was measured with a Carl Zeiss Jena micrometer eye-piece and micrometer slide. The standard steam distillation procedure was used for estimating extracellular ammonia (Bremner, I965).

\section{RESULTS}

Rapid growth occurred on transferring the batch cultures from the conical flasks to the fermentor after dilution with fresh nitrate medium (Fig. I). Thorough mixing in the fermentor facilitated the high rate of growth which was registered at an agitation rate of nearly $1000 \mathrm{rev}$. min. The steep fall in average filament length (Fig. I) did not seem to hamper growth.

After switching the culture to the continuous phase, three steady-state levels were obtained when the corresponding flow rates were 125,350 and $420 \mathrm{ml}$./day (dilution rates of $0.2 \mathrm{I}, 0.58$ and 0.70 respectively). The first steady state was obtained only after 7 days because of the low dilution rate, whereas the second and third steady states were obtained within 2 days after switching to a new rate.

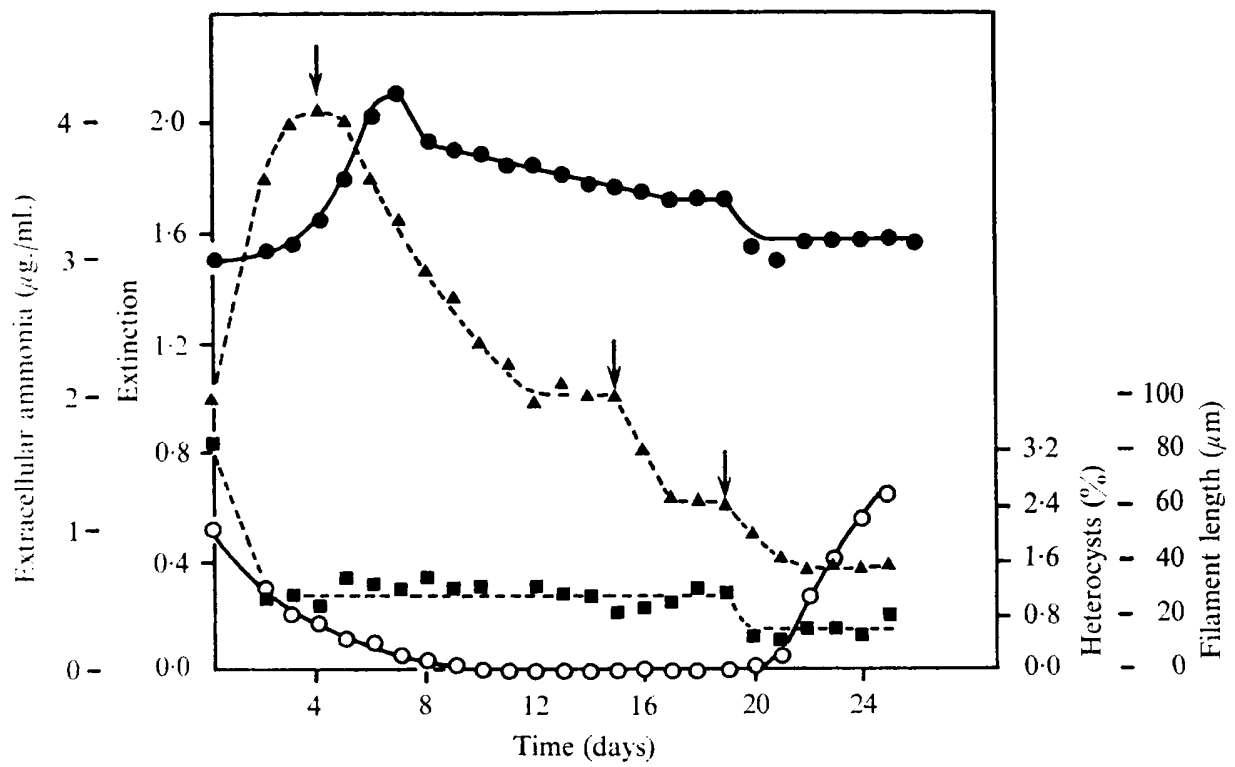

Fig. I. Growth of Anabaena sp. L-3 I in continuous culture; relation between extracellular ammonia and induction of heterocysts. $\boldsymbol{\Delta}-\boldsymbol{\Delta}$, Extinction; first arrow indicates switching from batch to continuous culture at a dilution rate of $0.2 \mathrm{I}$, second and third arrows indicate change of dilution rate to 0.58 and 0.70 respectively. - - Extracellular ammonia/ml. of algal suspension. $\square$ - $\square$, Length of filaments. $O-O$, Number of heterocysts, as percentage of total cells. 
The frequency of heterocysts (Fig. I) declined with growth in nitrate medium and reached a value of zero before the first steady-state phase. There was no change in this value during the first and second steady-state phases of growth. However, induction of heterocysts was observed one day after switching to the third dilution rate. Thereafter, frequency of heterocysts increased linearly with time. At this stage the average filament length declined further, which suggested that breakage of filaments was facilitated by heterocysts (Fig. I).

Extracellular ammonia (Fig. I) decreased with the decline in turbidity, and heterocysts were induced when the ammonia concentration had fallen from 4.2 to $3 \mu \mathrm{g} . / \mathrm{ml}$.

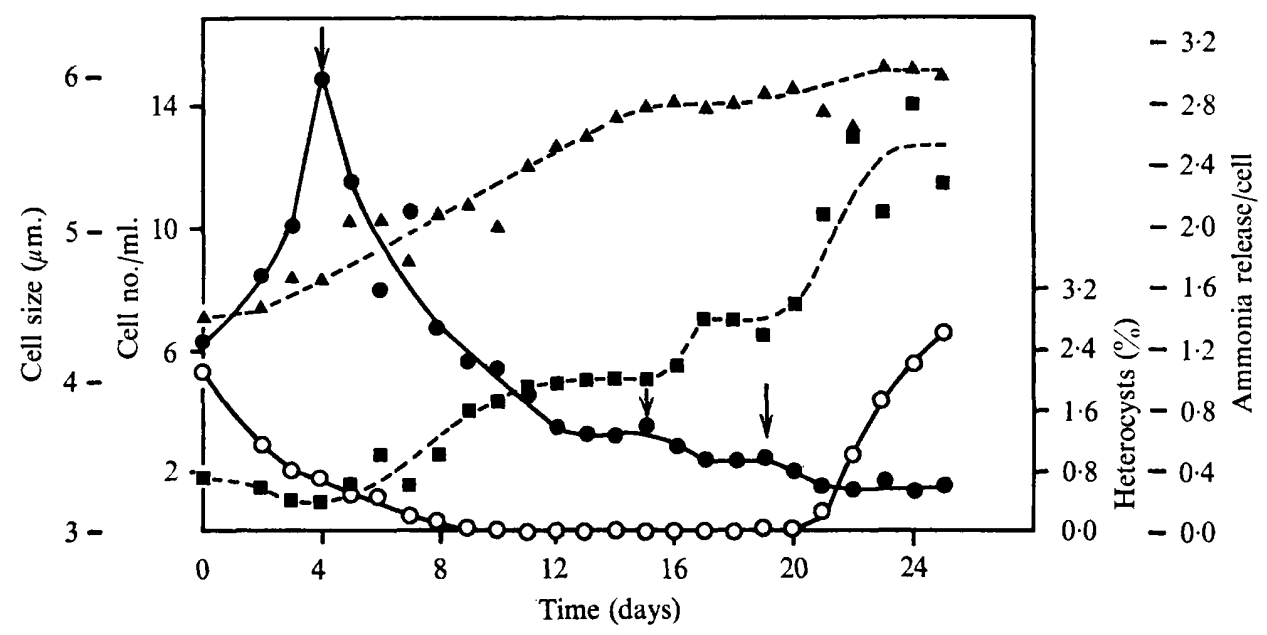

Fig. 2. Growth of Anabaena sp. L-3I in continuous culture; relation between cell number, release of ammonia/cell, cell size and heterocyst induction. - - Cell number $/ \mathrm{ml}$.; values in units of $10^{8}$. $\Delta--\Delta$, Cell size. $\bigcirc-O$, Number of heterocysts, as percentage of total cells. $\mathbf{E}-\cdots$, , Release of ammonia/cell; values in units of $\mu \mathrm{g}$. $10^{-10}$.

In continuous culture, release of ammonia per cell increased with increasing dilution rate and the consequent decrease in cell number (Fig. 2). Negative correlation was observed between the first two steady-state values for cell number and release of ammonia per cell. During the third steady-state phase, release of ammonia per cell increased greatly, showing a distinct correlation with induction of new heterocysts (Fig. 2). The inverse relation between release per cell and cell number was independent of the type of experiment. In Fig. 3 values from different experiments for release of ammonia per cell are plotted against cell number and the data include cultures in batch and continuous phases of growth. Induction of heterocysts occurred in all cultures when the release of ammonia per cell exceeded $2 \times 10^{-10} \mu \mathrm{g}$. or more.

The cells invariably enlarged with increase in dilution rate in continuous culture (Fig. 2). This enlargement, however, did not compensate for the reduction in cell number. The increase in cell size amounted to only $35 \%$, whereas cell number was reduced by $90 \%$. There was an apparent relation between increase in cell size and release of ammonia per cell (Fig. 2). However, cell size alone did not seem to account for the increase in ammonia release (Fig. 3). That is, the straight-line relationship observed between increasing ammonia release per cell and decreasing cell number was still maintained when the product of cell number and cell size was taken as an index of growth and not cell number alone.

The rate of growth increased considerably in continuous culture (Table I). In batch cultures fresh synthesis of cell material was $20.5 \mathrm{mg}$./day, whereas in continuous culture this 
increased to $23.5 \mathrm{mg}$. during the first dilution rate and more than doubled $(45.0 \mathrm{mg} . /$ day) during the second dilution rate. This enhanced rate was retarded $(36.4 \mathrm{mg}$./day) during the third dilution rate, possibly by excessive washing out of the suspension.

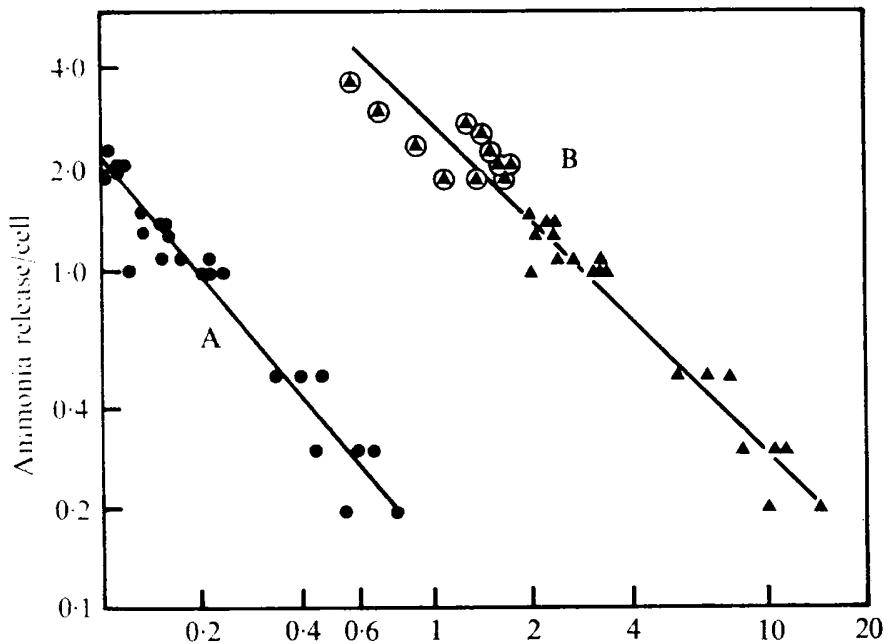

A. Cell no. $x$ cell size $\quad$ B. Cell no.

(arbitrary units)

Fig. 3. Relation between release of ammonia/cell, cell number and heterocyst induction. Data include values from different experiments. Values for cell number are in units of $10^{8}$ and for release of ammonia in units of $\mu \mathrm{g}$. $10^{-10}$. Circled triangles denote correlation with induction of heterocysts. See text for details.

Table I. Growth of Anabaena sp. L-3 I in continuous and batch cultures

$\begin{array}{cc}\text { Dilution rate* } & \begin{array}{c}\text { Algal mass pro- } \\ \text { duced per day (mg.) }\end{array} \\ 0.21 & 23.5 \\ 0.58 & 45.0 \\ 0.70 & 36.4 \\ \text { Batch culture } & 20.5 \\ \text { * ml. medium inflow per day/ml. steady-state volume of culture. }\end{array}$

\section{DISCUSSION}

Although many forms of combined nitrogen have been known to inhibit heterocyst production the physiology of this inhibition is not clear. Fogg (1949) suggested that low intracellular level of a reduced nitrogeneous substance, probably ammonia, causes normal cells to differentiate into heterocysts, though no experimental confirmation is available so far. The present results are in agreement with Fogg's suggestion and clearly endorse our earlier findings (Thomas et al. 1970).

Although high levels of extracellular ammonia showed correlation with inhibition of heterocysts, the release of ammonia per cell was more significant. The production of cellular ammonia through nitrate assimilation sustained the increase in growth rate during the first and second steady states in continuous culture. During the third steady state, however, further increase in dilution rate enhanced the rate of ammonia release per cell and it seems reasonable to conclude that consequently there was substantial reduction in the cellular level 
of ammonia. Under these conditions the requirement of cellular ammonia did not seem to be met by nitrate assimilation, and heterocysts were induced, possibly permitting the organism to compensate for this reduced availability of ammonia by converting molecular nitrogen to ammonia.

Recently Stewart, Haystead \& Pearson (1969) produced strong biochemical evidence indicating the location of nitrogen-fixing activity in heterocysts. High oxygen tension is known to inhibit nitrogenase activity (Fay \& Cox, 1967) and we (Thomas, 1970; Thomas et al. 1970) have demonstrated the absence in heterocysts of photosystem II of photosynthesis responsible for the evolution of molecular oxygen. The present results also support the view that heterocysts are the possible sites of nitrogen fixation in blue-green algae. However, Smith \& Evans (1970) observed distinct nitrogenase activity in vegetative cells of Anabaena cylindrica which cast some doubt on heterocysts as the sole sites of nitrogen fixation.

We thank Dr A. R. Gopal-Ayengar, Director, Bio-Medical Group, Bhabha Atomic Research Centre, Trombay, for his constant encouragement and interest.

\section{REFERENCES}

Bremner, J. M. (1965). In Methods of Soil Analysis, part II: Chemical and Microbiological Properties, p. I 17. Madison, Wisconsin: American Society of Agronomy.

Desikachary, T. V. (1959). Cyanophyta, p. 30. New Delhi: Indian Council of Agricultural Research.

FAY, P. \& CoX, R. M. (1967). Oxygen inhibition of nitrogen fixation in cell-free preparations of blue-green algae. Biochimica et biophysica acta 143, 562-569.

FAY, P., KUMAR, H. D. \& FOGG, G. E. (1964). Cellular factors affecting nitrogen fixation in the blue-green alga Chlorogloea fritschii. Journal of General Microbiology 35, 35I-360.

Fay, P., Stewart, W. D. P., Walsby, A. E. \& FogG, G. E. (1968). Is the heterocyst the site of nitrogen fixation in blue-green algae? Nature, London 220, 810-812.

FoGG, G. E. (1942). Studies on nitrogen fixation by blue-green algae. I. Nitrogen fixation by Anabaena cylindrica Lemm. Journal of Experimental Biology 19, 78-87.

FoGG, G. E. (1949). Growth and heterocyst production in Anabaena cylindrica Lemm. II. In relation to carbon and nitrogen metabolism. Annals of Botany 13, 241-259.

Mickelson, J. C., DAvis, E. B. \& Tischer, R. G. (1967). The effect of various nitrogen sources upon heterocyst formation in Anabaena flos-aquae A-37. Journal of Experimental Botany 18, 397-405.

PANDEY, D. C. \& MitRA, A. K. (1962). Production of heterocysts in certain Myxophyceae as influenced by the concentration of nitrogen in the medium. Naturwissenschaften 49, 89-9I.

Smith, R. V. \& Evans, M. C. W. (1970). Soluble nitrogenase from vegetative cells of the blue-green alga Anabaena cylindrica. Nature, London 225, 1253-1254.

STEWART, W. D. P. (1964). Nitrogen fixation by Myxophyceae from marine environments. Journal of General Microbiology 36, 415-422.

Stewart, W. D. P., Fitzgerald, G. P. \& BurRis, R. H. (1968). Acetylene reduction by nitrogen-fixing bluegreen algae. Archiv für Mikrobiologie 62, 336-348.

Stewart, W. D. P., Haystead, A. \& Pearson, H. W. (1969). Nitrogenase activity in heterocysts of filamentous blue-green algae. Nature, London 224, 226-228.

TALPASAYI, E. R. S. \& KALE, K. S. (I967). Induction of heterocysts in the blue-green alga Anabaena ambigua. Current Science 36, 218-219.

THомаs, J. (1970). The absence of the pigments of photosystem II of photosynthesis in heterocysts of a bluegreen alga. Nature, London 228, I8I-I83.

Thomas, J., David, K. A. V. \& Gopal-AyenGaR, A. R. (1970). On the biology of heterocysts in blue-green algae. In Proceedings of the First International Symposium on the Taxonomy and Biology of Blue-green Algae. University of Madras, Madras, India. (In the Press.)

WATANABE, A. (1960). Collection and cultivation of nitrogen-fixing blue-green algae and their effect on the growth and crop yield of rice plants. In Proceedings of the Symposium on Algology, p. I62. New Delhi: Indian Council of Agricultural Research. 